\title{
Hubungan antara Gurah Hujan dan Peningkatan Kasus Demam Berdarah Dengue Anak di Kota Palembang
}

\author{
Yulia Iriani \\ Bagian Ilmu Kesehatan Anak Fakultas Kedokteran Universitas Sriwijaya/RS Mohammad Hoesin, Palembang
}

\begin{abstract}
Latar belakang. Dampak curah hujan terhadap prevalensi dengue sangat penting untuk diteliti sebagai alat untuk meramalkan variasi insidens dan risiko yang berhubungan dengan dampak perubahan iklim.

Tujuan. Untuk menilai apakah peningkatan curah hujan di Palembang, setelah selang waktu tertentu, berhubungan dengan peningkatan jumlah kasus DBD anak yang dirawat di tiga rumah sakit di Palembang. Kedua, menilai hubungan puncak curah hujan dengan puncak kasus DBD yang dirawat. Jumlah kasus DBD yang dirawat di tiga rumah sakit tersebut diasumsikan mencerminkan tingkat kejadian DBD di Kota Palembang.

Metode. Data curah hujan didapat dari Badan Meteorologi Klimatologi dan Geofisika kota Palembang. Prevalensi DBD yang dirawat dikompilasikan dari buku/Data Register. Hubungan peningkatan curah hujan dengan peningkatan jumlah kasus DBD ditelusuri melalui olah statistik. Hubungan puncak curah hujan dengan puncak kasus DBD yang dirawat dinilai berdasarkan selang waktu antara puncak curah hujan dan puncak prevalensi perawatan kasus.

Hasil. Terdapat korelasi antara curah hujan dan peningkatan jumlah kasus DBD yang dirawat. Korelasi mulai terjadi satu bulan sebelum puncak curah hujan $(r=0,332 ; p=0,001)$, meningkat saat puncak curah hujan $(r=0,353 ; p=0,000)$, dan menurun satu bulan sesudahnya $(r=0,262 ; p=0,008)$. Bulan serta tanggal curah hujan berhimpitan dengan prevalensi kasus yang DBD yang dirawat. Anomali bulan puncak hujan diikuti perubahan puncak prevalensi DBD.

Kesimpulan. 1) Curah hujan berkorelasi dengan kejadian DBD, korelasi paling kuat terjadi dengan kasus DBD pada puncak curah hujan; 2) Puncak curah hujan bulanan berhimpitan dengan bulan puncak kasus DBD dan perubahan puncak curah hujan sejalan dengan perubahan puncak kasus DBD. Sari Pediatri 2012;13(6):378-83.
\end{abstract}

Kata kunci: DBD, curah hujan

Alamat korespondensi:

Dr. Yulia Iriani, Sp.A. Bagian IKA FK UNSRI/RS Mohammad Hoesin. Jalan Jendral Sudirman Km 3,5 Palembang. Telp. (0711) 414954. E-mail: riarusdi@yahoo.com

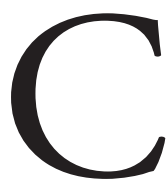

urah hujan merupakan salah satu faktor penentu kejadian infeksi dengue [demam dengue (DD) dan demam berdarah dengue (DBD)] selain faktor penentu lainnya, diantaranya iklim (suhu, kelembaban, dan lain-lain), densitas virus, serta herd immunity. ${ }^{1}$ Di sebagian besar 
negara, epidemi dengue dilaporkan terjadi selama musim hujan, lembab dan hangat, yang mendukung pertumbuhan nyamuk serta mempersingkat masa inkubasi ekstrinsik. ${ }^{2-5}$ Diaz-Qujiano $\mathrm{dkk}^{6}$ melaporkan terdapat asosiasi yang bermakna antara rerata curah hujan dalam lima minggu dan jumlah kasus yang melakukan konsultasi kesehatan untuk DD pada empat minggu sesudahnya pada tahun 2008 di Bogota Columbia.

Penelitian dilakukan untuk menelusuri apakah kecenderungan serupa terdapat di Palembang. Pertama, apakah peningkatan curah hujan di Palembang setelah selang waktu tertentu berhubungan dengan peningkatan kasus DBD yang dirawat di bangsal anak di tiga rumah sakit besar di kota Palembang. Kedua, bagaimana puncak curah hujan berhubungan dengan puncak kasus DBD yang dirawat. Jumlah kasus DBD yang dirawat di tiga rumah sakit ini diasumsikan dapat mencerminkan tingkat kejadian DBD di Kota Palembang, sehingga kecenderungan yang ditemukan dapat digunakan sebagai pijakan bagi pemangku kepentingan penanggulangan DBD di Kota Palembang dalam mengantisipasi lonjakan kejadian DBD sejalan dengan peningkatan curah hujan.

\section{Metode}

Data penelitian diperoleh secara retrospektif, meliputi data curah hujan dan jumlah kasus DBD yang dirawat di tiga rumah sakit besar di Palembang (RS Mohammad Hoesin, RS RK Charitas, dan RS Myria) selama tahun 2004-2010. Data diolah dengan menggunakan program SPSS Statistics 17.0.

Data curah hujan setiap bulan selama tahun 20042010 diperoleh dari Badan Meteorologi Klimatologi dan Geofisika (BMKG) Stasiun Klimatologi Klas II Kenten Palembang yang dinyatakan dalam satuan milimeter $(\mathrm{mm})$. Puncak curah hujan adalah curah hujan tertinggi di setiap tahun pengamatan. Bulan saat puncak curah hujan terjadi disebut sebagai bulan puncak hujan.

Prevalensi pasien DBD anak yang dirawat diperoleh dari Buku/Data Register Pasien Rawat Inap dan dikompilasikan per bulan untuk tahun 2004 sampai dengan 2010. Diagnosis DBD ditegakkan berdasarkan definisi kasus DBD menurut WHO tahun 1997.

Untuk menilai kecenderungan pertama, yaitu apakah peningkatan curah hujan di Palembang setelah selang waktu tertentu berhubungan dengan peningkatan kasus DBD yang dirawat inap, kurva curah hujan perbulan dan jumlah kasus DBD per bulan dipadankan. Olah statistik dilakukan dengan menilai koefisien korelasi Spearman serta tingkat kemaknaan antara tingkat curah hujan dan jumlah kasus DBD yang dirawat pada bulan yang sama, satu bulan sebelumnya, satu bulan sesudahnya, dan seterusnya.

Untuk menilai kecenderungan kedua, yaitu hubungan puncak curah hujan dengan puncak kasus DBD, dilakukan penilaian selisih waktu (hari) antara puncak curah hujan dan puncak kasus DBD. Bulan dengan curah hujan tertinggi serta bulan dengan jumlah kasus DBD tertinggi diidentifikasi. Hari titik puncak curah hujan dihitung berdasarkan angka curah hujan satu bulan setelah puncak curah hujan tertinggi dibagi dengan penjumlahan angka curah hujan satu bulan sebelum dan sesudah puncak tertinggi dikalikan 30. Angka yang didapat ditetapkan sebagai tanggal curah hujan tertinggi. Tanggal titik puncak kasus DBD dihitung dengan cara yang sama.

\section{Hasil}

Data curah hujan di Kota Palembang serta jumlah kasus DBD yang dirawat di bangsal anak di tiga Rumah Sakit di Palembang setiap bulan, mulai dari bulan Januari 2004 sampai dengan bulan Desember 2010, tertera pada Tabel 1 dan Gambar 1. Selama periode tahun 2004 - 2010, curah hujan tertinggi (puncak curah hujan) terjadi pada bulan Maret yaitu $733 \mathrm{~mm}$, sedangkan curah hujan terendah terjadi pada bulan Agustus yaitu $146 \mathrm{~mm}$.

Gambar 1 memperlihatkan perubahan curah hujan setiap bulan selama tahun 2004 - 2010 dipadankan dengan jumlah kasus DBD. Pada Gambar 1 tampak kasus DBD mulai meningkat dua bulan sebelum puncak curah hujan terjadi dan puncak kasus DBD pada tiap tahun pengamatan sebagian besar bersamaan dengan puncak curah hujan atau bergeser satu bulan sebelum dan sesudahnya.

Hasil penilaian hubungan antara tingkat curah hujan perbulan dengan kasus DBD melalui uji korelasi Spearman disarikan dalam Tabel 2. Terdapat korelasi antara curah hujan dan peningkatan jumlah kasus DBD yang dirawat. Korelasi mulai terjadi satu bulan sebelum puncak curah hujan $(\mathrm{r}=0,332 ; \mathrm{p}=0,001)$, meningkat saat puncak curah hujan $(r=0,353 ; p=0,000)$, dan melemah 
Yulia Iriani: Hubungan antara curah hujan dan kasus DBD

Tabel 1. Jumlah kasus DBD dan curah hujan setiap bulan selama tahun $2004-2010$

\begin{tabular}{|c|c|c|c|c|c|c|c|c|c|c|c|c|c|}
\hline \multirow{2}{*}{ Tahun } & \multirow{2}{*}{ Variabel } & \multicolumn{12}{|c|}{ Bulan } \\
\hline & & Jan & Feb & Mar & Apr & Mei & Jun & Jul & Aug & Sep & Okt & Nov & Des \\
\hline \multirow[t]{2}{*}{2004} & $\mathrm{CH}(\mathrm{mm})$ & 257 & 191 & 414 & 197 & 243 & 64 & 230 & 37 & 32 & 156 & 227 & 255 \\
\hline & Jumlah kasus & 31 & 60 & 128 & 61 & 47 & 27 & 25 & 19 & 41 & 27 & 51 & 73 \\
\hline \multirow[t]{2}{*}{2005} & $\mathrm{CH}(\mathrm{mm})$ & 249 & 224 & 413 & 225 & 249 & 182 & 170 & 67 & 151 & 157 & 242 & 223 \\
\hline & Jumlah kasus & 147 & 109 & 109 & 47 & 57 & 43 & 35 & 38 & 31 & 44 & 50 & 77 \\
\hline \multirow[t]{2}{*}{2006} & $\mathrm{CH}(\mathrm{mm})$ & 360 & 253 & 420 & 285 & 92 & 191 & 120 & 10 & 1 & 0 & 135 & 221 \\
\hline & Jumlah kasus & 105 & 100 & 110 & 87 & 100 & 98 & 106 & 91 & 68 & 63 & 89 & 211 \\
\hline \multirow[t]{2}{*}{2007} & $\mathrm{CH}(\mathrm{mm})$ & 503 & 179 & 208 & 379 & 187 & 130 & 98 & 3 & 58 & 114 & 123 & 382 \\
\hline & Jumlah kasus & 495 & 434 & 258 & 212 & 176 & 121 & 90 & 50 & 42 & 33 & 83 & 159 \\
\hline \multirow[t]{2}{*}{2008} & $\mathrm{CH}(\mathrm{mm})$ & 204 & 143 & 372 & 323 & 48 & 24 & 150 & 175 & 61 & 319 & 634 & 232 \\
\hline & Jumlah kasus & 188 & 143 & 115 & 125 & 158 & 111 & 93 & 93 & 125 & 145 & 238 & 334 \\
\hline \multirow[t]{2}{*}{2009} & $\mathrm{CH}(\mathrm{mm})$ & 275 & 134 & 564 & 339 & 112 & 140 & 36 & 97 & 33 & 212 & 184 & 284 \\
\hline & Jumlah kasus & 268 & 174 & 139 & 94 & 76 & 57 & 72 & 70 & 55 & 74 & 110 & 169 \\
\hline \multirow[t]{2}{*}{2010} & $\mathrm{CH}(\mathrm{mm})$ & 251 & 325 & 542 & 420 & 243 & 171 & 91 & 194 & 371 & 254 & 520 & 249 \\
\hline & Jumlah kası & 26 & 174 & 139 & 94 & 76 & 57 & 72 & 70 & 55 & 74 & 110 & 169 \\
\hline \multirow{2}{*}{\multicolumn{2}{|c|}{ Rerata curah hujan $(\mathrm{mm})$}} & 525 & 362 & 733 & 542 & 293 & 225 & 224 & 146 & 177 & 303 & 516 & 461 \\
\hline & $\mathrm{CH}$ tertinggi $(\mathrm{mm})$ & 503 & 325 & 564 & 420 & 249 & 191 & 230 & 194 & 371 & 319 & 634 & 382 \\
\hline
\end{tabular}

Keterangan: $\mathrm{CH}=$ curah hujan

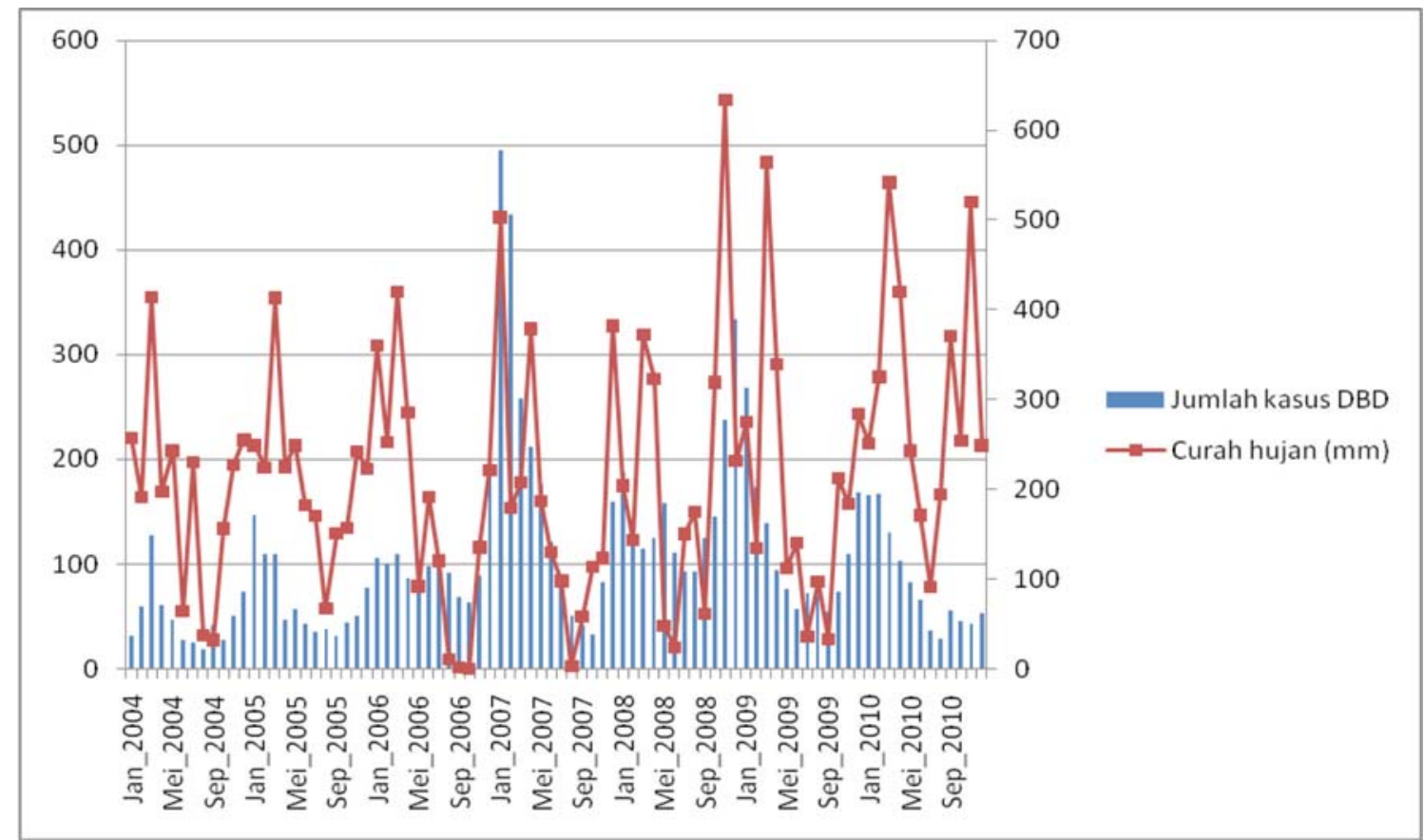

Gambar 1. Distribusi kasus DBD sesuai curah hujan setiap bulan selama tahun 2004 - 2010

satu bulan sesudahnya $(\mathrm{r}=0,262 ; \mathrm{p}=0,008)$.

Tabel 3 memperlihatkan bulan puncak curah hujan dan puncak kasus DBD dalam satu tahun kalender dari tahun 2004 sampai dengan tahun 2010. Sebagian besar bulan puncak curah hujan terjadi pada bulan Maret, kecuali pada tahun 2007 dan 2008. Puncak kasus DBD sebagian besar terjadi pada saat bulan puncak curah hujan. Rerata selisih waktu antara puncak curah hujan dan puncak kasus DBD adalah -1,4 (SD 2,1) hari dengan media 0 (range $-4-2$ ) hari. 
Tabel 2. Korelasi antara curah hujan dan kasus DBD

\begin{tabular}{|c|c|c|c|c|c|}
\hline \multirow{2}{*}{\multicolumn{2}{|c|}{$\begin{array}{l}\text { Variabel curah hujan disandingkan dengan jumlah } \\
\text { kasus DBD anak yang dirawat }\end{array}$}} & \multicolumn{2}{|c|}{ Curah hujan } & \multirow{2}{*}{$\begin{array}{c}\text { Jumlah } \\
\text { bulan } \\
\text { pengamatan }\end{array}$} & \multirow{2}{*}{$\begin{array}{c}\text { Jumlah } \\
\text { tahun } \\
\text { pengamatan }\end{array}$} \\
\hline & & $\begin{array}{l}\text { Koefisien } \\
\text { korelasi }\end{array}$ & $\mathrm{p}^{*}$ & & \\
\hline \multirow{7}{*}{$\begin{array}{l}\text { Jumlah } \\
\text { penderita } \\
\text { DBD }\end{array}$} & $\begin{array}{l}\text { Pada bulan yang sama dengan puncak } \\
\text { curah hujan }\end{array}$ & 0,353 & 0,000 & 84 & 7 \\
\hline & 1 bulan sesudah puncak curah hujan & 0,262 & 0,008 & 83 & 7 \\
\hline & 2 bulan sesudah puncak curah hujan & 0,107 & 0,168 & 82 & 7 \\
\hline & 3 bulan sesudah puncak curah hujan & $-0,065$ & 0,284 & 81 & 7 \\
\hline & 1 bulan sebelum puncak curah hujan & 0,332 & 0,001 & 83 & 7 \\
\hline & 2 bulan sebelum puncak curah hujan & 0,180 & 0,052 & 82 & 7 \\
\hline & 3 bulan sebelum puncak curah hujan & $-0,124$ & 0,135 & 81 & 7 \\
\hline
\end{tabular}

* Spearman correlation

Tabel 3. Puncak curah hujan dan puncak kasus DBD

\begin{tabular}{|c|c|c|c|c|c|c|c|}
\hline \multirow{2}{*}{ Variabel } & \multicolumn{7}{|c|}{ Tahun pengamatan } \\
\hline & 2004 & 2005 & 2006 & 2007 & 2008 & 2009 & 2010 \\
\hline Bulan puncak $\mathrm{CH}$ & Maret & Maret & Maret & Januari & November & Maret & Maret \\
\hline $\begin{array}{l}\text { Curah hujan pada bulan } \\
\text { puncak } \mathrm{CH}(\mathrm{mm})\end{array}$ & 414 & 413 & 420 & 503 & 634 & 564 & 542 \\
\hline $\begin{array}{l}\text { Jumlah DBD pada bulan } \\
\text { puncak CH }\end{array}$ & 128 & 109 & 110 & 495 & 238 & 139 & 130 \\
\hline $\begin{array}{l}\text { Curah hujan } 1 \text { bulan } \\
\text { sebelum puncak } \mathrm{CH}\end{array}$ & 191 & 224 & 253 & 221 & 319 & 134 & 325 \\
\hline $\begin{array}{l}\text { Jumlah DBD } 1 \text { bulan } \\
\text { sebelum puncak } \mathrm{CH}\end{array}$ & 60 & 109 & 100 & 211 & 145 & 174 & 167 \\
\hline $\begin{array}{l}\text { Curah hujan } 1 \text { bulan setelah } \\
\text { puncak } \mathrm{CH}\end{array}$ & 197 & 225 & 285 & 179 & 232 & 339 & 420 \\
\hline $\begin{array}{l}\text { Jumlah DBD } 1 \text { bulan } \\
\text { setelah puncak } \mathrm{CH}\end{array}$ & 61 & 47 & 87 & 434 & 334 & 94 & 103 \\
\hline $\begin{array}{l}\text { Perkiraan tanggal puncak } \\
\mathrm{CH}\end{array}$ & 15 & 15 & 16 & 13 & 13 & 22 & 17 \\
\hline $\begin{array}{l}\text { Perkiraan tanggal puncak } \\
\text { jumlah DBD }\end{array}$ & 15 & 12 & 16 & 10 & 9 & 20 & 19 \\
\hline $\begin{array}{l}\text { Selisih hari puncak jumlah } \\
\text { DBD dan CH (hari) }\end{array}$ & 0 & -3 & 0 & -3 & -4 & -2 & +2 \\
\hline
\end{tabular}

Keterangan: $\mathrm{CH}=$ curah hujan

\section{Pembahasan}

Transmisi dengue berkorelasi dengan curah hujan, temperatur serta kelembaban. Efek curah hujan terhadap prevalensi dengue sangat penting untuk diteliti karena diperlukan sebagai alat untuk meramalkan variasi insidens dan risiko yang berhubungan dengan dampak perubahan iklim. ${ }^{7}$ Gambaran grafis dalam Gambar 1 secara jelas memperlihatkan hubungan antara curah hujan dan jumlah kasus DBD anak yang dirawat. Hasil pengamatan didukung oleh uji statistik melalui uji korelasi Spearman dengan koofisien korelasi 0,353 serta $\mathrm{p}=0,000$. Jika curah hujan dipadankan dengan jumlah kasus DBD satu bulan sesudahnya, koofisien korelasi melemah menjadi 0,262 serta $\mathrm{p}$ menjadi 0,008. Jika dipadankan dengan jumlah kasus DBD dua bulan serta tiga sesudahnya, korelasi menjadi 
tidak bermakna. Jumlah kasus DBD satu bulan sebelum puncak curah hujan juga memiliki korelasi dengan curah hujan (Tabel 2).

Berdasarkan hasil olah statistik melalui uji korelasi Spearman, jika asumsi bahwa jumlah kasus DBD di tiga rumah sakit di Palembang dapat mencerminkan kejadian DBD di kota Palembang dapat diterima, maka dapat disimpulkan bahwa peningkatan curah hujan akan meningkatkan kejadian DBD di kota Palembang. Peningkatan kasus akan mulai terjadi satu bulan sebelum puncak curah hujan terjadi, menjadi semakin nyata pada bulan berikutnya, dan menetap sampai satu bulan setelah puncak curah hujan terjadi, kemudian menyusut kembali setelah bulan kedua, dan dampaknya akan menghilang setelah bulan ketiga.

Curah hujan dapat meningkatkan transmisi penyakit yang ditularkan oleh vektor dengan cara memacu proliferasi tempat berkembang biak, tetapi juga dapat mengeliminasi tempat berkembang biak dengan cara menghanyutkan vektor. Hal ini mungkin dapat menjelaskan mengapa korelasi yang didapatkan pada penelitian ini tidak terlalu kuat (moderat). ${ }^{8}$ Faktor iklim lainnya yang tidak ditelti [kelembaban, suhu, ENSO (El Niño Southern Oscillation) $]^{8}$ perlu dipertimbangkan untuk menyokong hasil penelitian ini.

Kajian epidemiologis yang lebih intensif mengenai infeksi dengue di Palembang saat terjadi kejadian luar biasa (KLB) pada bulan Januari sampai dengan April 1998, berdasarkan kasus yang dirawat di rumah sakit selama enam tahun sebelumnya, telah dilaporkan oleh tim peneliti dari NAMRU. ${ }^{9}$ Selain memperlihatkan peranan iklim terhadap kejadian infeksi dengue, penelitian kami juga memperkirakan pengaruh klimatik ENSO terhadap munculnya KLB. ${ }^{7}$ Meskipun penelusuran Johanson $\mathrm{dkk}^{10}$ hanya menemukan asosiasi yang lemah antara dampak ENSO sekitar 1998 terhadap kejadian DD/ DBD di Thailand dan Puertorico, tetapi mereka memperkirakan ENSO mengubah pola dinamika penyebaran dan interaksi virus dengue secara transnasional.

Gambar 1 serta Tabel 3 memperlihatkan puncak curah hujan, baik tanggal maupun bulan terjadinya, berhimpitan dengan puncak kasus DBD. Temuan ini mendukung kesimpulan bahwa curah hujan berhubungan dengan kejadian DBD. ${ }^{7,11}$ Walaupun peningkatan jumlah pasien DBD menetap sampai satu bulan setelah puncak curan hujan, akan tetapi temuan ini tidak sepenuhnya sejalan dengan dengan temuan Diaz-Qujiano dkk, ${ }^{6}$ yang memicu penelitian ini, bahwa "setelah terjadi peningkatan selama 5 minggu, akan terjadi peningkatan kasus DD selama 4 minggu sesudahnya." Ketidakselarasan ini mungkin dapat diterangkan melalui kenyataan bahwa sebelum puncak curah hujan tercapai, peningkatan curah hujan sebenarnya telah terjadi secara bertahap 3 sampai 4 bulan sebelumnya (Tabel 1 dan Gambar 1). Hal tersebut menyebabkan dampak curah hujan terhadap peningkatan kasus DBD secara bertahap telah terakumulasi sampai ke ambang di atasnya.

Kami mendapatkan puncak curah hujan dan puncak kasus DBD terjadi pada bulan Maret, kecuali pada tahun 2007 terjadi pada bulan Januari dan tahun 2008 pada bulan November. Apakah anomali kedua puncak ini disebabkan oleh anomali cuaca, tidak dapat dipastikan jawabannya berdasarkan data yang ada. Akan tetapi laporan kami memperlihatkan, anomali puncak curah hujan dari rata-rata tahunan akan diikuti pula dengan perubahan puncak kasus DBD. Puncak curah hujan juga tetap terjadi pada waktu yang sama dengan puncak kasus DBD.

Berdasarkan pengamatan tingkat curah hujan bulanan di Kota Palembang serta jumlah kasus DBD setiap bulan yang dirawat di tiga RS di Palembang selama tahun 2004 sampai dengan tahun 2010, dengan asumsi bahwa jumlah kasus DBD ini mencerminkan kejadian DBD di Kota Palembang, dapat disimpulkan sebagai berikut, 1) Tingkat curah hujan berkorelasi dengan jumlah kasus DBD, korelasi paling kuat terjadi pada bulan puncak curah hujan, 2) Bulan puncak curah hujan berhimpitan dengan bulan puncak kasus DBD, dan 3) Perubahan puncak curah hujan sejalan dengan perubahan puncak kasus DBD.

\section{Daftar pustaka}

1. Halstead SB. Epidemiology. Dalam: Halstead SB, penyunting. Dengue. London: Imperial College Press;2008.

2. Gibbons RV, Vaughn DW. Dengue: an escalating problem. BMJ 2002;324:1563-6.

3. Innis BL. Dengue and dengue hemorrhagic fever. Dalam: Proterfield JS, penyunting. Kass handbook of infectious diseases: exotic virus infections. London: Chapman and Hall Medical;1995.h.103-46.

4. Rigau-Perez JG, Clark GG, Gubler DJ, Reiter P, Sanders EJ, Vorndam AV. Dengue and dengue hemorrhagic fever. Lancet 1998;352:971-7. 
5. McBride WJ, Bielefeldt-Ohmann H. Dengue viral infections: pathogenesis and epidemiology. Microbes Infect 2000;2:1041-50.

6. Díaz-Quijano F, González-Rangel A, Gómez-Capacho A. Rainfall and acute febrile syndrome in a dengueendemic area. Rev Salud Publica;2008:10:250 9[Abstract].

7. Wiwanitkit V. An observation on correlation between rainfall and the prevalence of clinical cases of dengue in Thailand. J Vect Borne Dis 2006;43:73-6.

8. Gharbi M, Quenel P, Gustave J, Cassadou S, Ruche GL, Girdary L dkk. Time series analysis of dengue incidence in Guadeloupe, French West Indies: Forecasting models using climate variables as predictors. BMC Inf Dis 2011;11:166-78.

9. Corwin AL, Larasati RP, Bangs MJ, Wuryadi S. Epidemic dengue transmission in Southern Sumatra, Indonesia. Trans R Soc Trop Med Hyg 2001;95:257-65.

10. Johansson MA, Cummings DAT, Glass GE. Multiyear climate variability and dengue-El Nin־o Southern oscillation, weather, and dengue incidence in Puerto Rico, Mexico, and Thailand: a longitudinal data analysis. PLoS Medicine 2009;6:1-9.

11. Gusman MG, Kouri G. Dengue and dengue haemorrhagic fever in the Americas: lessons and challenges. J Clin Virol 2003;27:1-13. 